\title{
Development of a weight-estimation model to use in pregnant criollo-type mares
}

\author{
Patricia Soares Vieira ${ }^{1}$ Carlos Eduardo Wayne Nogueira ${ }^{1}$ Alice Correa Santos ${ }^{1}$ \\ Luciana de Araujo Borba ${ }^{1}$ Rebeca Scalco ${ }^{1}$ Carolina Litchina Brasil $^{1}$ \\ Willian Silva Barros ${ }^{2}$ Bruna da Rosa Curcio ${ }^{1 *}$
}

'Departamento de Clínicas Veterinária, Faculdade de Veterinária, Universidade Federal de Pelotas (UFPel), 96010-610, Pelotas, RS, Brasil. E-mail: curciobruna@hotmail.com. "Corresponding author.

${ }^{2}$ Departamento de Matemática e Estatística, Instituto de Física e Matemática, Universidade Federal de Pelotas (UFPel), Capão do Leão, RS, Brasil.

ABSTRACT: The aims of this study were: 1) to compare the tape weight and associated weight-estimation formula to evaluate weight gain in pregnant mares, and 2) to develop a mathematical model to estimate the weight of pregnant mares using body measurements. Thirty-four criollotype mares were evaluated every two weeks during the middle and late pregnancy. The mares were weighed on a livestock scale, and we estimated body weight using tape weights and an associated body-weight estimation formula. Also, heart-girth circumference (heartgirth) and abdominal circumference were measured; the latter at the $12^{\text {th }}$ intercostal space (12 $2^{\text {th }}$ ICS) and $18^{\text {th }}$ rib (18 ${ }^{\text {th }}$ Rib), to use in a mathematical model to estimate the weight of pregnant mares. Observations were divided into three periods of pregnancy: $5^{\text {th }}$ to $7^{\text {h }}$ month, $7^{\text {th }}$ to $9^{\text {h }}$ month, and $9^{\text {th }}$ to $11^{\text {th }}$ month Mares in late pregnancy showed an increase in actual weight and an increase in $12^{\text {th }} I C S$ and $18^{\text {th }}$ Rib measurements. Tape weight and body-weight estimation formula underestimated the weight of pregnant mares. However, the regression model using heart-girth circumference, $12^{\text {th }}$ ICS, and $18^{\text {th }}$ Rib measurements showed high correlation $\left(r^{2}=0.87, P<0.001\right)$ with actual weight. Finally, the alternative methods usually used in horses are not accurate to estimate body weight in pregnant mares. In conclusion, the regression model $Y=-540.143+$ (heartgirth $x 3.068)+\left(12^{\text {th }}\right.$ ICS $x$ $1.278)+\left(18^{\text {th }}\right.$ Rib $\left.x 0.944\right)$ can be used to estimate body weight in pregnant mares from the $5^{\text {th }}$ to $11^{\text {th }}$ months of pregnancy.

Key words: pregnant mares, weight tape, body weight estimation.

Modelo para estimativa de peso em éguas gestantes mestiças crioulas

RESUMO: Este estudo teve como objetivos: 1) comparar a utilização dos métodos alternativos fita de pesagem e peso metabólico em éguas gestantes e; 2) desenvolver um modelo matemático para estimar o peso de éguas gestantes, baseado em medidas corporais. Trinta e quatro éguas foram avaliadas quinzenalmente durante o terço médio e final da gestação. Foi realizada a pesagem em balança comercial; a mensuração com a fita de peso para equinos; o cálculo do peso metabólico; as medidas de perímetro torácico (Ptorac); a mensuração abdominal no décimo segundo espaço intercostal (12EI) e na décima oitava costela (18Cost). As observações foram divididas em três periodos gestacionais: Período de 5 a 7 meses, Periodo de 7 a 9 meses e Período de 9 a 11 meses. As éguas demonstraram incremento no peso na balança e na mensuração abdominal no 12EI e 18Cost no terço final da gestação. A utilização da fita de pesagem e o cálculo de peso metabólico subestimaram o peso na balança em éguas gestantes. O modelo de regressão utilizando o Ptorac, 12EI e 18Cost apresentou alta correção $\left(r^{2}=0,87 ; P<0,001\right)$ com o peso na balança. Observou-se que os métodos alternativos de pesagem, usualmente utilizados, não apresentaram a mesma eficiência em éguas prenhes. Pode-se concluir que o modelo de regressão $\mathrm{Y}=-540,143+($ Ptorac X 3,068) $+(12 E I X$ $1,278)+\left(18\right.$ Cost X 0,944) pode ser utilizado para mensurar o peso em éguas gestantes a partir do $5^{\circ}$ mês de gestação.

Palavras-chave: gestação, fita peso, peso estimado.

\section{INTRODUCTION}

Body weight is an essential indicator of equine health and is used in equine management, including designing feeding programs and administering medication (WAGNER \& TYLER, 2011). In human medicine, body weight measurement is used as a method to follow fetal development and weight gain in pregnant women (MARTINELLI et al., 2001; CASTELLANO FILHO et al., 2012).
Similar measures in horses also could be used to monitor pregnant mares.

The major weight gain in pregnant mares occurs during the second trimester of gestation. The increase in body weight and body condition score are due to fat storage, which aims to supply the energy demand of the growing fetus (LAWRENCE et al., 1992). Body weight gain in last trimester of gestation is due to an increase in fetal weight and an increase in body weight of the pregnant mare (PLATT, 1984). 
Livestock scale is a tool to evaluate the actual weight of livestock; however, the scale is often not available at horse farms. Alternative methods could also be used, based on body measurement, such as tape weight and associated body-weight estimation formulas available for horses (WAGNER \& TYLER, 2011). Alternative methods cannot always be used for pregnant mares in the third trimester, because of the biometric changes occurring in this period and the changeability of heart-girth circumference in these animals (SERRA et al., 2012).

Alternative methods for estimating the weight of horses are widely used on the field, especially, the weight tape. Thereby, the need to validate alternative methods for estimating body weight of pregnant mares has been identified. Therefore, the goals of the present study were: 1) to compare the use of alternative methods to estimate body weight (weight tape and associated body-weight estimation formula) in pregnant mares during the second and third trimesters of pregnancy; and 2) to develop a mathematical model, based on body measurements, to estimate body weight of pregnant mares during the second and third trimesters of the pregnancy.

\section{MATERIALS AND METHODS}

Thirty-four pregnant criollo-type mares were evaluated in this study during the second and third trimesters of gestation $\left(5^{\text {th }}\right.$ to $11^{\text {th }}$ month of gestation). The mares were 7-12 years old, height $137.11 \pm 5.1 \mathrm{~cm}$ (CV 3.7\%) and body length average during the fifth month of gestation was $155.97 \pm 7.8 \mathrm{~cm}$ (CV 5.0\%). Mares presented body condition scores of 5-7 (HENNEKE et al., 1983) throughout the study. Variation in mean body condition scores occurred due to changes in individual scores. All mares were housed at Centro de Ensino e Experimentação em Equinocultura da Palma (CEEEP), of the Universidade Federal de Pelotas (UFPel), Capão do Leão, Brasil. Mares were housed at uniform sanitary conditions and nutritional management: provided with pasture and supplemented with commercial concentrate pellets and water ad libitum.

Actual weight of horses was measured on a mechanical livestock scale (Cauduro Ltda., Cachoeira do Sul, RS, Brasil). The alternative method to estimate body weight were the weight tape and associated body-weight estimation formula. The weight tape used (Suprivet ${ }^{\circledR}$, Divinópolis, MG, Brasil) has an interval from 80 to $192 \mathrm{~cm}$, which correspond to 41 to $540 \mathrm{~kg}$. The estimation formula was calculated using heart-girth circumference (heartgirth) and body length $(B L)$, which were applied to the formula: heartgirth ${ }^{2}+B L 11880$, previously described by HALL (1971) and later used by CARROLL \& HUNTINGTON (1988) and WAGNER \& TYLER (2011).

Measurement of BL was performed using the longitudinal distance from the scapulohumeral joint to the ischiatic tuberosity (as previously described by WAGNER \& TYLER, 2011). Heartgirth circumference (heartgirth) was measured after an exhalation by placing the tape behind the elbow and passing it in a straight vertical line over the withers and across the sternum (WAGNER \& TYLER, 2011). Also, abdominal circumference was measured at the $12^{\text {th }}$ intercostal space and the $18^{\text {th }}$ rib, after exhalation, as described elsewhere (CARROLL \& HUNTINGTON, 1988). All these measurements were collected using a conventional tape (nylon strap), $2 \mathrm{~m}$ in length.

Biometric monitoring was performed biweekly, starting with the fifth month of gestation (155 days) and continuing until the foaling day. All measurements were collected on the same evaluation day. During the study, 14 evaluations were performed in 34 mares (total of $n=476$ observations). Four cases were excluded from this total due to anticipated foaling and unreliability of the last evaluation (total of $n=472$ observations). For data analysis, observations were divided into three-time intervals according to the gestational period: from $5^{\text {th }}$ to $7^{\text {th }}$ month (155-212 days), $n=124$; from $7^{\text {th }}$ to $9^{\text {th }}$ month (213-272 days), $n=177$; and from $9^{\text {th }}$ to $11^{\text {th }}$ month (273 days until parturition), $n=171$. The difference between actual weight and alternative methods for estimating body weight methods (weight tape, estimation formula, and mathematical regression model) was calculated as described by WAGNER \& TYLER (2011).

Statistical analysis was performed using Statistix $10.0^{\circledR}$ (Analytical Software, Tallahassee, FL, USA). Normality was assessed by the Shapiro-Wilk test, assuming parametric distribution of all variables. Continuous data were expressed as mean $\pm \mathrm{SD}$ within gestation periods and were analyzed using a oneway ANOVA. When main effects were significant, post hoc comparisons were made using a Tukey test. Statistical significance was set at $\mathrm{P}<0.05$.

Several regression analyses were performed and multiple linear regression model was reported to be the most adequate. Best Subsets Regression (insert citation) Model was used to identify predictor variables of future responses of actual weight in pregnant mares. Variables with the highest $r^{2}$ value in relation to actual weight were then used in our linear regression analysis $(\mathrm{P}<0.05)$. 


\section{RESULTS}

The description of body measurements according to the gestational periods are shown in table 1. Relationship between weight and biometric variables in each gestational period (as indicated by Best Subset Regression) was as follows: 1) Heart-girth circumference: $5^{\text {th }}$ to $7^{\text {th }}$ month $\left(r^{2}=0.71\right) ; 7^{\text {th }}$ to $9^{\text {th }}$ month $\left(\mathrm{r}^{2}=0.80\right) ; 9^{\text {th }}$ to $11^{\text {th }}$ month $\left(\mathrm{r}^{2}=0.76\right)$; overall gestation $\left.\left(r^{2}=0.76\right) ; 2\right) 12^{\text {th }}$ intercostal space: $5^{\text {th }}$ to $7^{\text {th }}$ month $\left(\mathrm{r}^{2}=0.70\right) ; 7^{\text {th }}$ to $9^{\text {th }}$ month $\left(\mathrm{r}^{2}=0.74\right) ; 9^{\text {th }}$ to $11^{\text {th }}$ month $\left(r^{2}=0.72\right)$; overall gestation $\left.\left(r^{2}=0.73\right) ; 3\right) 18^{\text {th }} \mathrm{Rib}: 5^{\text {th }}$ to $7^{\text {th }}$ month $\left(\mathrm{r}^{2}=0.67\right) ; 7^{\text {th }}$ to $9^{\text {th }}$ month $\left(\mathrm{r}^{2}=0.72\right) ; 9^{\text {th }}$ to $11^{\text {th }}$ month $\left(r^{2}=0.67\right)$; overall gestation $\left(r^{2}=0.70\right)$.

The Best Subset Regression comparison between weight estimation in relation to the body measurements (heart-girth circumference, $12^{\text {th }}$ ICS and $\left.18^{\text {th }} \mathrm{Rib}\right)$ and $\mathrm{r}^{2}$ value observed were: 1) $5^{\text {th }}$ to $7^{\text {th }}$ month $\left.\left(\mathrm{r}^{2}=0.83\right) ; 2\right) 7^{\text {th }}$ to $9^{\text {th }}$ month $\left(\mathrm{r}^{2}=0.88\right)$; and 3$) 9^{\text {th }}$ to $11^{\text {th }}$ month $\left(r^{2}=0.87\right)$. Comparison between the independent regression models of the gestational periods showed $\mathrm{r}^{2}=0.87$.

In the evaluation of the set of variables body length, heart-girth circumference, abdominal measurement in the $12^{\text {th }}$ intercostal space and 18th rib, $\mathrm{r}^{2}$ values were: 1$) 5^{\text {th }}$ to $7^{\text {th }}$ month $\left.\left(\mathrm{r}^{2}=0.83\right) ; 2\right) 7^{\text {th }}$ to $9^{\text {th }}$ month $\left.\left(r^{2}=0.88\right) ; 3\right) 9^{\text {th }}$ to $11^{\text {th }}$ month $\left(r^{2}=0.89\right)$; and overall gestational periods $\left(r^{2}=0.87\right)$.

Heart-girth circumference, as well as abdominal measurements at the $12^{\text {th }}$ intercostal space and $18^{\text {th }}$ rib, were used to create a mathematical regression that can be used in daily practice of monitoring weight of pregnant mares. Because $r^{2}$ values observed for regression models of each gestational period and for all gestational periods combined were very close, a multiple linear regression model was built for all gestational periods combined (Figure 1).
From this model, mean weights of pregnant mares were calculated according to the gestational period and described in table 2. table 3 shows the differences reported between the actual and estimated weights of pregnant mares by gestational period.

\section{DISCUSSION}

Based on the changes in abdominal measurement, a regression model was developed for estimating weight of pregnant mares from the fifth month of gestation until parturition. In addition to heart-girth circumference, which has been applied in other formulas for estimating body weight, the abdominal measurements in the $12^{\text {th }}$ ICS and $18^{\text {th }}$ rib were included in our model. In multiple linear regression analysis, we demonstrated the association between the variables used in the formula $\left(r^{2}=0.87\right.$, $\mathrm{P}<0.001)$ and the weight gain of mares throughout gestation (Figure 1).

The application of the proposed regression model, $Y=-540.143+($ heartgirth $\times 3.068)+\left(12^{\text {th }} \mathrm{ICS}\right.$ $x 1.278)+\left(18^{\text {th }}\right.$ Rib $x$ 0.944), resulted in a smaller difference $(4 \%)$ relative to the actual weight. It was possible to identify weight gain in the $9^{\text {th }}$ to $11^{\text {th }}$ months of gestation from weights estimated from the regression model (which was founded in the actual weight). The use of abdominal measurement in the $12^{\text {th }}$ ICS and the $18^{\text {th }}$ rib allowed us to evaluate the abdominal increase of pregnant mares, which occurs mainly during the gestational period close to parturition. Our results showed that the established regression model is more accurate than others weight-estimation models for the monitoring of weight gain in pregnant mares.

The increase observed in abdominal circumference at the $12^{\text {th }}$ ICS and $18^{\text {th }}$ rib during the $9^{\text {th }}$ to $11^{\text {th }}$ months of gestation resulted from abdominal

Table 1 - Results of mean \pm SD (minimum and maximum values) heart girth circumference (heart girth), abdominal circumference at the $12^{\text {nd }}$ intercostal space $\left(12^{\text {th }}\right.$ ICS) and at the $18^{\text {th }}$ rib $\left(18^{\text {th }}\right.$ Rib), actual weight and estimated weight (tape weight and formula), according to the gestational trimester: Period from $5^{\text {th }}$ to $7^{\mathrm{h}}$ month; Period from $7^{\text {th }}$ to $9^{\text {th }}$ month and Period from $9^{\text {th }}$ to $11^{\text {th }}$ month of gestation.

\begin{tabular}{lccc}
\hline Variables & $5^{\text {th }}$ to $7^{\text {th }}$ month $(\mathrm{n}=124)$ & $7^{\text {th }}$ to $9^{\text {th }}$ month $(\mathrm{n}=177)$ & $9^{\text {th }}$ to $11^{\text {th }}$ month $(\mathrm{n}=171)$ \\
\hline Heart-girth $(\mathrm{cm})$ & $164.8^{\mathrm{a}} \pm 6.8(151-182)$ & $165.6^{\mathrm{a}} \pm 7(140-182)$ & $166.6^{\mathrm{a}} \pm 8.4(140-180)$ \\
Abdominal circumference $12^{\text {th }} \mathrm{ICS}(\mathrm{cm})$ & $191.4^{\mathrm{b}} \pm 10.6(159-224)$ & $191.3^{\mathrm{b}} \pm 10.7(143-216)$ & $198.5^{\mathrm{a}} \pm 10.8(173-228)$ \\
Abdominal circumference $18^{\text {th }} \mathrm{Rib}(\mathrm{cm})$ & $186.3^{\mathrm{b}} \pm 11.2(157-218)$ & $187.8^{\mathrm{b}} \pm 12.0(160-222)$ & $194.9^{\mathrm{a}} \pm 12.7(161-225)$ \\
Actual weight $(\mathrm{kg})$ & $386.7^{\mathrm{Ab}} \pm 43.9(294-518)$ & $389.2^{\mathrm{Ab}} \pm 47.9(255-511)$ & $407.9^{\mathrm{Aa}} \pm 51.5(282-513)$ \\
Tape weight $(\mathrm{kg})$ & $376.9^{\mathrm{Aa}} \pm 41.3(290-465)$ & $381.8^{\mathrm{Aa}} \pm 49.3(245-500)$ & $387.5^{\mathrm{Ba}} \pm 52.2(240-490)$ \\
Formula $(\mathrm{kg})$ & $357.6^{\mathrm{Bb}} \pm 41.4(275-482)$ & $364.4^{\mathrm{Bab}} \pm 44.6(254-479)$ & $373.5^{\mathrm{Ca}} \pm 47.9(250-482)$ \\
\hline
\end{tabular}

${ }^{a . b}$ Different letters within row denote differences with ANOVA one-way, Tukey's test $(\mathrm{P}<0.05)$.

A.B.C Different letters within columns denote differences with ANOVA one-way, Tukey's test $(\mathrm{P}<0.05)$. 


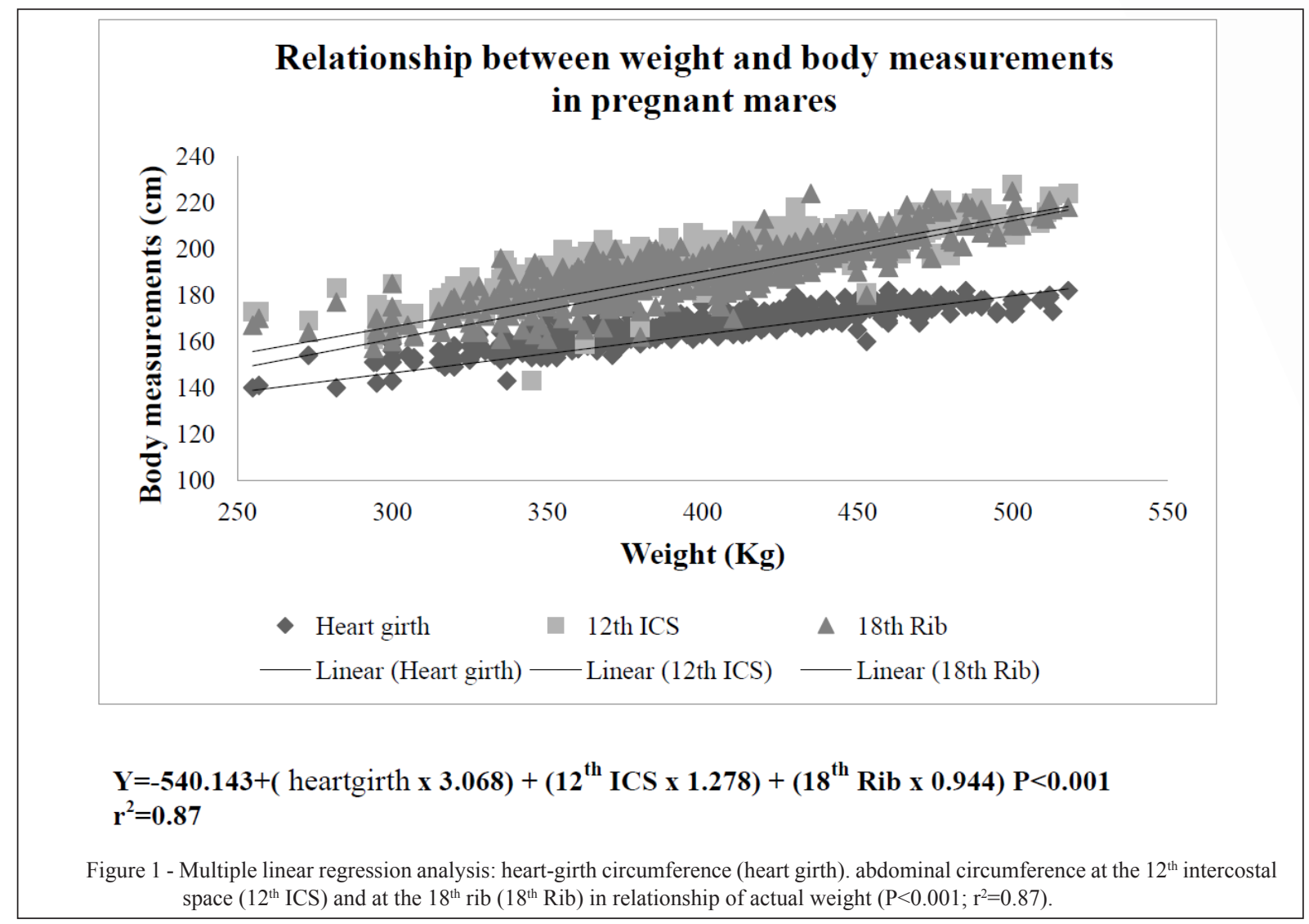

expansion to accommodate fetal growth. The abdominal region presents more apparent biometric changes in the final trimester of gestation than heart-girth circumference due to fetal development and growth, since at least $50 \%$ of this occurs in the last trimester of gestation (PLAT, 1984). Unlike abdominal circumference, the heartgirth circumference does not change due to gestation, as observed in our study. Heart-girth circumference and consequently, tape weight, did not show differences across gestational periods.

The use of the tape weight is a method widely used in field practice; however, a study carried out on adult horses of different ages and weights showed that this method underestimated weights of horses and demonstrated it was not the most accurate way to estimate body weight (WAGNER \& TYLER,

Table 2 - Results of mean $\pm \mathrm{SD}$ (minimum and maximum values) of actual weight and regression model $\mathrm{Y}=-540.143+$ (heartgirth $\mathrm{x}$ $3.068)+(12 \mathrm{ICS} \times 1.278)+(18 \mathrm{Rib} \times 0.944)$, according to the gestational trimester: Period from $5^{\text {th }}$ to $7^{\mathrm{h}}$ month; Period from $7^{\text {th }}$ to $9^{\text {th }}$ month and Period from $9^{\text {th }}$ to $11^{\text {th }}$ month of gestation.

\begin{tabular}{lccc}
\hline Variable & $5^{\text {th }}$ to $7^{\text {th }}$ month $(\mathrm{n}=124)$ & $7^{\text {th }}$ to $9^{\text {th }}$ month $(\mathrm{n}=177)$ & $9^{\text {th }}$ to $11^{\text {th }}$ month $(\mathrm{n}=171)$ \\
\hline Actual weight $(\mathrm{kg})$ & $386.7^{\mathrm{b}} \pm 43.9(294-518)$ & $389.2^{\mathrm{b}} \pm 47.9(255-511)$ & $407.9^{\mathrm{a}} \pm 51.5(282-513)$ \\
Regression model $(\mathrm{kg})$ & $392.1^{\mathrm{b}} \pm 42.9(277-510)$ & $387.6^{\mathrm{b}} \pm 44.7(268-510)$ & $405.8^{\mathrm{a}} \pm 3.62(274-519)$ \\
\hline
\end{tabular}

a.b Different letters within row denote differences with ANOVA one-way, Tukey's test $(\mathrm{P}<0.05)$.

There was no difference between values of weight on actual weight and regression model in the columns with ANOVA one-way $(\mathrm{P}>0.05)$. 
Table 3 - Differences ${ }^{*}($ Mean \pm SEM) between actual and estimated weight in pregnant mares according to the gestational trimester: Period from $5^{\text {th }}$ to $7^{\text {h }}$ month; Period from $7^{\text {th }}$ to $9^{\text {th }}$ month and Period from $9^{\text {th }}$ to $11^{\text {th }}$ month of gestation.

\begin{tabular}{lccc}
\hline & Difference $(\mathrm{Kg})$ & Difference $(\mathrm{Kg})$ & Difference $(\mathrm{Kg})$ \\
\cline { 2 - 4 } Estimation weight tools & $5^{\text {th }}$ to $7^{\text {th }}$ month & $7^{\text {th }}$ to $9^{\text {th }}$ month & $9^{\text {th }}$ to $11^{\text {th }}$ month \\
\cline { 2 - 4 } & $\mathrm{n}=124$ & $\mathrm{n}=177$ & $\mathrm{n}=171$ \\
Tape weight & $29.9^{\mathrm{b}} \pm 1.6(7.7 \%)$ & $21.3^{\mathrm{b}} \pm 1.2(5.3 \%)$ & $22.6^{\mathrm{b}} \pm 1.4(5.6 \%)$ \\
Formula & $34^{\mathrm{a}} \pm 1.8(8.8 \%)$ & $28^{\mathrm{a}} \pm 1.3(7.2 \%)$ & $36.2^{\mathrm{a}} \pm 2.2(8.9 \%)$ \\
Regression model & $13.5^{\mathrm{c}} \pm 1.2(3.4 \%)$ & $12.3^{\mathrm{c}} \pm 0.8(3.1 \%)$ & $16.3^{\mathrm{c}} \pm 2.4(4.0 \%)$ \\
\hline
\end{tabular}

"Difference = Actual weight - estimated weight (as described by Wagner e Tyler. 2011);

a.b.c Different letters within columns denote differences with ANOVA one-way, Tukey's test $(\mathrm{P}<0.05)$.

2011). Also in our study, we observed that weight in pregnant mares was underestimated using this method, with a mean difference of 21.33 to $29.92 \mathrm{~kg}$ in different gestational periods (Table 3), resulting in a mean difference of $<7 \%$ of the actual weight. It is important to emphasize that the weight obtained through the tape-weight method did not show any difference between gestational periods, while as the actual weight increased in the period from the $9^{\text {th }}$ to $11^{\text {th }}$ months of gestation. These measures suggested that tape-weight method is not the most accurate method to monitor weight gain in pregnant mares.

The formula to weight calculation $\mathrm{Y}$ $=\left(\right.$ heartgirth $\left.^{2}+B L\right) / 11880$ is based on heart-girth circumference and body length, and was indicated as the most effective alternative method to estimate weights of non-pregnant horses (WAGNER \& TYLER, 2011). We did not observe mean weights calculated with this formula to be lower in relation to the actual weight; however, tape weight did not reflect weight gain that occurred during the final trimester of gestation, corroborating with results of LAWRENCE et al. (1992). The formula had an average difference of 27.99 to $36.19 \mathrm{~kg}$ (Table 3), resulting in a mean difference of $-8 \%$ compared to the actual weight. Therefore, in light of the differences reported, we emphasize that the tapeweight formula is not an ideal alternative method for estimating body weight of pregnant mares. Ability to estimate the body weight of horses in the absence of a livestock scale has been already determined to be important. The development of a specific, tape-weight estimation for pregnant mares may be an alternative to minimize misunderstandings caused using traditional tape-weight estimates.

\section{CONCLUSION}

In conclusion, the multiple linear regression model $\mathrm{Y}=-540.143+$ (heartgirth $\times 3.068)+\left(12^{\text {th }}\right.$
ICS $\times 1.278)+\left(18^{\text {th }}\right.$ Rib $x$ 0.944 $)$ presented a strong correlation with the weight gain in pregnant mares from the fifth month of gestation until foaling. Given that, in the absence of a livestock scale, this model can be used to estimate the weight of mares in this category. The use of the tape weight and the estimation of body weight with the associated formula underestimated the actual weight in pregnant mares in the second and third trimesters of gestation.

\section{ACKNOWLEDGMENTS}

The authors thank the Coordenação de Aperfeiçoamento de Pessoal de Nível Superior (CAPES) for the scholarships to graduate students enrolled in the Programa de Medicina Veterinária da Universidade Federal de Pelotas.

\section{BIOETHICS AND BIOSSECURITY COMMITTEE APPROVAL}

All procedures were approved by the Comite de Ética em Experimentação Animal (CEEA) of the Universidade Federal de Pelotas under the protocol number 7026-2015.

\section{REFERENCES}

CARROLL, C.L.; HUNTINGTON, P.J. Body condition scoring and weight estimation of horses. Equine Veterinary Journal. v.20, p.41-45, 1988. Available from: <http://onlinelibrary.wiley.com/ doi/10.1111/j.2042-3306.1988.tb01451.x/epdf>. Accessed: May. 27, 2016. doi: 10.1111/j.2042-3306.1988.tb01451.x.

CASTELLANO FILHO, D.S., et al. Waist circumference measured before the $12^{\text {th }}$ week of pregnancy: correlation with serum leptin levels. Revista Brasileira de Ginecologia e Obstetrícia. v.34, p.268-73, 2012. Available from: <http://www.scielo.br/scielo. php?pid=S0100-72032012000600005\&script $=$ sci_arttext $>$. Accessed: May. 20, 2016. doi: 10.1590/S0100-72032012000600005.

HALL, L.W. Wright's veterinary anaesthesia and analgesia. London: Baillière Tindall, 1971. 176p.

HENNEKE, D.R., et al. Relationship between condition score, physical measurements and body fat percentage in mares. Equine 
Veterinary Journal. v.15, p.371-2, 1983. Available from: $<$ http:// onlinelibrary.wiley.com/doi/10.1111/j.2042-3306.1983.tb01826.x/ epdf $>$. Accessed: May. 18, 2016. doi: 10.1111/j.2042-3306.1983. tb01826.x.

LAWRENCE, L.M. et al. Changes in body weight and condition of gestating mares. Journal Equine Veterinary Science. v.12, p.355358, 1992. Available from: <http://www.j-evs.com/article/S07370806(06)81361-4/pdf>. Accessed: May. 27, 2016. doi: 10.1016/ S0737-0806(06)81361-4.

MARTINELLI, S. et al. M. Proposal of a new uterine height growth curve for pregnancies between 20 and 42 weeks. Revista Brasileira de Ginecologia e Obstetrícia. v.23, p.235241，2001. Available from: <http://www.scielo.br/pdf/rbgo/ v23n4/11364.pdf > . Accessed: May. 26, 2016. doi: 10.1590/S010072032001000400006 .
PLATT, H. Growth of the equine fetus. Equine Veterinary Journal. v.16, p.247-252, 1984. Available from: <http://onlinelibrary.wiley. com/doi/10.1111/j.2042-3306.1984.tb01920.x/epdf>. Accessed: May. 27, 2016. doi: 10.1111/j.2042 3306.1984.tb01920.x.

SERRA, S. F. et al. Correlação entre fita de pesagem corporal e balança na determinação do peso de equinos para dosificação de fármacos. Campinas, SP, 2012. In: XIII Conferência Anual Abraveq, 2012, Campinas, SP. Anais... Available from: <http:// www.itarget.com.br/newclients/abraveq2012/down/manejoartigo_0014.pdf>. Accessed: May, 27, 2016.

WAGNER, E.L.; TYLER, P.J.A. Comparison of weight Estimation Methods in Adult Horses. Journal of Equine Veterinary Science. v.31, p.706-710, 2011. Available from: <http://www.j-evs.com/ article/S0737-0806(11)00352-2/pdf > . Accessed: May. 27, 2016. doi: 10.1016/j.jevs.2011.05.002. 